\title{
Globalization and Its Dimensions of Education Inequalities: With Special Reference to Karnataka
}

\author{
${ }^{1}$ N.Somashekar And ${ }^{2}$ Vinodh Kumar G.C. \\ ${ }^{1}$ Assistant Professor, National College, Bagepalli, Karnataka, India. \\ 2 Junior Research Fellows, Department of Sociology, Bangalore University, India.
}

\begin{abstract}
Education is the most important tool for development of any society. In India, higher education has been beneficial for some but not for all streams of the society. There is a need to make the process more inclusive because some millions of people in the country have seen almost no rewards. The results of globalization are mixed. The benefits have not reached the majority and new risks have emerged for the socially deprived and rural poor. It has also created socio-economic and cultural disparities in the society. The disparities are found in creating a gap between caste, class and communities. The present education system has failed to inclusive of equal opportunity to entire section of the society. This development has led to the unequal distribution of socio- economic standard of the society. There is a need to study inclusive of all sections of the society for providing equal standard of education and equal opportunity for the major sections of the society for the development of nation.
\end{abstract}

Keywords: Cultural aspect, Economic inequality, Globalization, Higher education \& Social inequality.

\section{Introduction:}

Education is universally recognized as the most powerful instrument of social change and it is also an indicator of social, cultural and healthy development of a country. A nation's development depends upon its ability to create skilled human resource through the promotion of quality education among its citizens. Education is essentially a social process that should not be viewed as an end in itself or merely a means for employment. This is also true. By higher education a person can able to increase his knowledge and expand his vision and avail the fruits or development. Hence higher education can play the role of "Catalyst" in bringing sea changes in the sphere of social, political, economic fields.

\section{Historical Roots Of Higher Education:}

Historical approaches to comparative education research can offer unique insights (Sweeting, 2005; Rury, 2006). The major higher education systems in all countries, regardless of ideology, economic system, or level of technological development, are based primarily on variations of the 19thcentury Western university model (Altbach, 1989). Faculties in various disciplines are expected both to teach post-secondary courses to groups of students and to do original research in their areas of specialty. Ideas of liberalism, academic freedom, and an emphasis on research, introduced into German universities in the early 1800s by Wilhelm von Humboldt, are represented in some form in the higher education institutions (HEIs) of China, India and the United States. Nonetheless, differences are apparent. To consider how national culture and context might influence application of the results of education research described above, it is helpful to explore briefly the ancient historical roots and more recent development of tertiary education in each country.

Many studies of university teaching have examined differences in general characteristics or organization of the education system of these three countries and the considerable variation in standards and curriculum that exists among them. (Gu, 2001; Altbach \& Umakoshi, 2004; Altbach et al., 2005; Agarwal, 2006, 2007). Other authors in this volume discuss differences in higher education policy and assessment issues. Still another distinction is that, in general, Asian students entering university or college have different levels of preparation than Americans. In India and for the most part, in China, students take two or three science and mathematics courses every year for five or six years in secondary school, while U.S. high school students normally take one science course and one math course for each of four high school years.

Several leading U.S. scientists and educational scholars active in the science education reform movement have introduced a "physics first" curriculum in a few school districts iii, but the concept has spread slowly. Information that focuses explicitly on the origins or use of instructional strategies that foster innovative problem-solving or the specifics of teacher-student dynamics in the classroom is scattered in the international literature of science education, developmental psychology and the cognitive sciences (e.g., Ho, 2001; Turner, 2006; Aggarwal, 2004). Our goal here is to explore some of those results as they apply specifically to India, China and America to see if or how differences in science instruction may have been influenced by local history or cultural context. 


\section{Higher Education In India:}

Indian culture is based on a reverence for education that extends back thousands of years. But modern HEIs in India have grown out of the British colonial regime of the mid-19th century, with its "anglicist" orientation in which higher education was primarily seen as serving the political and economic interests of the British. The language of instruction for most courses was English, and subjects in the humanities and languages were favored, rather than in the sciences or technical areas. Growth of higher education in the country has generally been divided by observers into three phases: ancient times to independence; 1947 to 1980; and 1980 to the present (Agarwal, 2006, 2007).

\section{Ancient Origin Of Indian University System:}

Indian higher education has its roots in the ancient Gurukul system that flourished during the Vedic era, possibly as early as $1500 \mathrm{BCE}$. Thriving centers of learning, termed Viharas, comparable to the early Chinese piyong, were established at Takshashila (Taxila, now in Pakistan) in the $6^{\text {th }}$ century BCE and at Vikramsila in the 5th century BCE. Students entered Takshashila at the age of 16 to study the Vedas and the Eighteen Arts, which included law, medicine and military science as well as skills such as archery, hunting and elephant lore. As Buddhism flourished in India, one of the world's first great residential universities arose at Nalanda in the $5^{\text {th }}$ century BCE. It had dormitories for 10,000 students and employed 2,000 teachers. The library was located in a nine-story building where copies of texts were meticulously produced. Although the primary focus of education at that time was on religion and philosophy, classes in virtually every field of learning were available and attracted pupils and scholars from around the world. Nalanda thrived as a university center for over 700 years, until the city was sacked by Muslim armies in 1193.

Much of India's long history of advanced thinking and teaching in mathematical and scientific inquiry derives from scholars at such HEIs (Aggarwal, 2004), who delved into profound questions of the universe, self, the role of the state, and social order, often applying notably modern methodologies of observation, conceptualization and verification. Long before the modern era of science in the West, India had made advances in mathematics with the invention of zero, the decimal system and the calculus, for example, and in a variety of scientific fields, especially in astronomy (e.g., first estimate of the distance to the sun), chemistry, metallurgy and physics (Lohia, 1998; Thadani, 2002). The Gurus or instructors in the nation's centers of learning were often also the scientists of the day. To a remarkable extent, learning was prized for its own sake, and the social status and intellectual freedom of teachers was great.

\section{The Contemporary University System In India:}

The modern system of higher education began over 150 years ago under British rule when policy guidelines, established by "Macaulay and Wood's Despatch" of 1854, led to the founding in 1857 of the first three Indian universities in Bombay, Calcutta and Madras. Because of Great Britain's prevailing paternalistic attitude, each of these was affiliated with a British institution. Modeled on the University of London (established in 1836), these institutions served mainly as affiliating and examining bodies, aimed at producing a small class of civil servants rather than promoting an intellectual life to benefit the society. The next 90 years saw a period of slow development of the system; only 18 new universities were established during that time, mainly in provincial capitals and port towns. They offered courses in literature, history, philosophy, political science, social science and the natural sciences, but emphasis was generally on Western liberal arts education with little focus on the sciences.

Indian independence in 1947, every aspect of India's educational system was based — and to a large extent continues to be based-on the British colonial legacy: educational levels, curriculum frameworks, physical structure of schools and classrooms, timing of examinations. Universities, empowered to award degrees, were established either by an act of Parliament or a State Legislature. Certain institutions were "deemed to be" a university according to a special provision of the University Grants Commission, in order to afford them degree-granting powers. The higher education system was small and fragmented, consisting of 25 universities and about 500 small colleges scattered throughout the country. It enrolled no more than 100,000 students. After independence, the country adopted a sequenced development approach, initially projecting three consecutive five-year plans to focus respectively on agriculture, industry and agro-based industry. Development of higher education in the past 60 years has been rapid. The number of HEIs increased 10-fold from about 500 in 1947 to 5,000 in 1980 and then to over 13,000 in the year 2000. A vast and dizzyingly complex infrastructure for this higher education system has been created which, according to the latest figures (2005-2006), now comprises 17,973 HEIs including 362 universities and "deemed" universities that award higher degrees and 17,625 colleges, many with a specific focus on arts, sciences, commerce, teacher training, medicine, law, engineering or other areas (Agarwal, 2006). "If India plays its cards right it can become by 2020 the world's number one knowledge production centre." With this forecast, R. A. Mashelkar (2005) stated the country's optimistic goal and its justification for the explosive rate of increase in the higher education system. 
In 1990, the system served about 4 million undergraduate students. By 2000, the student population had doubled to over 8 million; as of the 2005-2006 academic year, it stood at almost 11 million. But this still represented a gross enrollment ratio of only 12 percent. Until the liberalization of the economy in the late 1990s, the university system was funded largely from public monies. Although private schools of medicine and engineering and a few privately funded colleges had existed for some time, growth of the private system was blocked until a series of specific decisions were made by governing bodies to allow private, autonomous institutions. The effect was dramatic. Between 2000 and 2005, 26 privately sponsored institutions obtained the deemed status.

The University Grants Commission, established in 1956, currently administers and provides complete funding for the 18 Central universities, while 141 deemed universities-including the prestigious Indian Institutes of Technology (IITs), Indian Institute of Science (IISc), Tata Institute of Fundamental Research (TIFR) and a host of other technology institutes of various kinds - as well as 203 State universities, are monitored by a welter of other agencies and coordinated by a series of 15 Professional Councils. State universities receive funding from central and state governments and from private sources. Professional Councils are responsible for recognition of courses, promotion of professional institutions, and providing funding for undergraduate programs. There is also an advisory agency, the Association of Indian Universities, and a layer of administrative bodies at the state level, the State Councils of Higher Education. In 2005, the government created the National Knowledge Commission (NKC) as a high-level advisory body to the prime minister, with a mandate to guide policy and direct reforms.

The expansion of the higher education system in India has been chaotic and largely unplanned. The swift rate of growth and the drive to make the system socially inclusive have resulted in a sudden and dramatic increase in numbers of institutions without a proportionate increase in funding or in intellectual resources. As a consequence, academic standards have suffered badly (Béteille, 2005). Employers complain about the lack of preparedness of graduates, and numerous institutions struggle to maintain accreditation (Stella, 2002; Popli, 2005, Russell, 2007; McGaw, Ch. 12, this volume). There are many basic problems facing the system. According to Agarwal (2006), these include inadequate infrastructure and facilities, faculty positions unfilled or filled with poorly trained instructors, outmoded forms of instruction, declining research standards, unmotivated students, overcrowded classrooms and widespread geographic, income, gender, and ethnic imbalances.

1994 report of the Indian Academy of Sciences, Bangalore, commenting on the state of science education in Indian colleges and universities concluded: the general view is that standards in all respects have declined rapidly and alarmingly, and unless something is done soon to remedy the situation, the country is definitely heading for disaster. (IASB, 1994) Despite the development over the past two decades of a few bright spots in the university system, a knowledgeable observer still finds it necessary to refer recently to the "dismal state of nearly all of the conventional centers of higher education" (Lakhotia, 2005). Altbach concludes that a major problem is lack of funds: India's colleges and universities, with just a few exceptions, have become large, under-funded, ungovernable institutions...Underinvestment in libraries, information technology, laboratories, and classrooms makes it very difficult to provide top-quality instruction or engage in cutting-edge research. (Altbach, 2005a, p. 2)

The IITs and a number of other well-known Indian institutions have gained justified praise for the superiority of their courses and their graduates. However, the quality of education received by students at many public and private for profit institutions has been called into question (e.g., Jayaram, 2004). There are far too few qualified faculty, and many departments are staffed by parttime, adjunct instructors. Just as in China and the United States, renowned Indian leaders and national panels have called for improvements in the university system and the undergraduate education in the sciences that it provides. In 1990, philosopher-scholar S. Radhakrishnan, often called the founder of the university system in India (Lavakare, 2006), saw the conditions in tertiary education so weakened that he felt compelled to remind his readers that "it is the universities that have to assume the leadership in the world of ideas and ideals," and expressed the fear that they were unable to do so (Radhakrishnan, 1990).

According to Andre Beteille, chairman of the Indian Council of Social Science Research, The universities are [rightly] attacked for allowing academic standards to decline steadily in a world in which knowledge is expanding rapidly...There is growing anxiety, particularly among our scientists, that India is losing its competitive advantage in the field of modern knowledge to China and other countries over which it had such an advantage until recently. If India is to advance or even keep its place as a knowledge society, it will have to invest far more in research and development and in the institutions of higher education. (Beteille, 2007, p. 243) Educators Sanjana Mehta and David Whitebread introduced a recent study with criticism that applies equally to secondary and tertiary education: The Indian education system is characterized by didactic teaching, individual work, a product oriented approach (output being entirely measured in terms of achievement in exams), absence of independent thinking and presence of unquestioned obedience to authority... The...system is highly effective in developing individuals who can be successful in situations where they have an authority to 
follow, but is not so effective in preparing individuals to deal with situations where they need to exercise their own judgment (Mehta \& Whitebread, 2004, p. 1).

It appears that few Indian leaders are thinking creatively about higher education and there is little ongoing research designed to answer questions about how to improve higher education in the country (Jayaram, 2004). While America has a vigorous field of education research and China's is growing, that of India appearswith a few notable exceptions - to be moribund.

India's historical valuing of learning and wisdom includes sensitivity to quality regarding education that dates back to ancient times. Hanh (1996) cites the Buddha's discourse as emphasizing correctness in the choice of knowledge and ways of teaching it. Both Mahatma Gandhi and the Nobelist poet-scholar Rabindranath Tagore were deeply interested in educational reform (Sykes, 1987).

The multi-cultural school that Tagore established in 1901 as an alternative to the poor system of education imposed by the British was an effort to combine the best of traditional Hindu education with Western ideals. Nonetheless, Indian higher education curricula have traditionally been based on teacher-directed, knowledge acquisition models of instruction (Popli, 2005). Recent calls to introduce more student-centered, knowledge-construction approaches (e.g., Narayanan \& Neethi, 2005) have thus far failed to bring about systemic change. However, the "bright spots" are becoming more apparent and are spreading. Rare examples of outstanding professors in a few universities (e.g., Bagla, 2007) and a new influx of faculty with training or experience in the West will likely bring new vigor and standards to both their research and teaching roles. Clearly needed is greater participation of the elite institutions in educating young scientists and the development of a healthy India-centered community of education researchers capable of creating or adapting new instructional methods to their nation's classrooms.

Globalization has created a complex phenomenon as well as it has a multi-dimensional impact on the society. In the field of education, the universities in India are primly concentrating its education towards development of human resources to the globalized labour market and neglecting the needs of promoting knowledge for the utilization of our resources and the development of large sections of the society. In India only $11 \%$ of the total populations are able to getting higher education. Among them $75 \%$ of the population belongs to urban elites, upper class and upper middle class but the other classes of the society consists of $25 \%$ which comprises $75 \%$ of the total population. This development has created socio-economic and cultural disparities in the society. The disparities are found creating a gap between caste, class and communities. This development has led to unequal distribution of socio-economic standard of the society.

\section{Objectives Of The Study:}

- To examine the impact of globalization on higher education.

- To examine the education inequality of social groups like class, caste and communities.

- To find out the gaps of enrolment in various socio-economic groups.

\section{Rationale Of The Study:}

The development of the globalization in India has drawn a huge attention of general public moreover a debate in international level regarding the higher education aspect. The India's scenario in the field of education is attaining a negative growth when compared to other developed countries. The Karnataka's scenario in the higher education is decreasing day by day. The concepts of caste, class and cultural aspects have led to the negative growth in higher education. The in and around places adjacent to the city centers in Karnataka are performing well in higher education but the large number of the places in Karnataka has not been beneficial in the aspect of higher education. The higher education system is not been reaching the general public, rural people and tribal people in Karnataka. In this regard there is a need to study and reframe the policies and programs regarding the higher education system for the better development of the society.

\section{Methodology Of The Study:}

This paper attempts to understand the globalization and its educational inequalities regarding the higher education in Karnataka. The study is based on secondary data collected from various sources such as, articles, journals, books, newspapers, governmental reports, educational reports and internet.

\section{Results And Discussions:}

The process of Liberalization Privatization Globalization entered India from 1990's and it is a complex phenomenon as well as it has a multi-dimensional impact several social institutions of the society including education. In India there are 20 central University, 215 states, and 100 deemed universities are working. Under this 17,000 colleges are able produce human capital for nation.

In Karnataka 17 universities bring out 12.14 percent graduates of total population of Karnataka state. The universities in India are primly concentrating its education towards development of human resources to the 
globalized labour market and neglecting the needs of promoting knowledge for the utilization of our resources, social justice and the development of large sections of the society.

In Karnataka the universities giving general degree education to 4, 01,548 students and 1, 01,049 students are able get professional degree education. Out of which 84, 518 students are opted engineering courses. It shows that, out of every 5 students in Karnataka, only 1 student is able to get professional courses. From this statistics majority of students are unable to get opportunity for professional degree courses.

In the same way the disparity can be found in urban and rural students. $82 \%$ of rural students are fall in general degree courses and $18 \%$ are getting opportunity to entering to the professional courses. Out of $23 \%$ of urban population only $7 \%$ elite, upper and upper middle class people are usurping the privileged education.

When we come across the education among the socio - economic group of Karnataka the situation is not much different by above disparity. The upper caste representing $7 \%$ of total populations of Karnataka $6.3 \%$ are literate and among them $60 \%$ are getting higher education. The OBC and SC are getting higher education $23 \%$ and $16 \%$ respectively, but the tribal population representing only $2 \%$ in this regard.

This development has created socio-economic and cultural disparities in the society. The disparities are found creating a gap between caste, class and communities. This development has also lead to unequal distribution of socio-economic standard of the society.

\section{Findings Of The Study:}

- The urban elite, upper class and upper middle class sections of the society are enjoying all the privileges of higher education and employment.

- Other remaining classes of the society like rural, tribal and lower classes have seen almost no rewards.

- The higher education in respect of globalization is creating a socio-economic as well as cultural gap in the society.

- Opportunities are been seized to major section of the society due to economic disability in context of higher education.

- The district-wise education reflects the serious imbalances in educational attainments across districts of Karnataka.

\section{SUGGESTIONS:}

- To provide equal educational opportunities for all sections of the society by implementing new policies and programmes.

- Creating awareness among the students in the rural and tribal areas about the higher education and opportunities in the society and motivating them to move towards professional and emerging new courses.

- Close down courses with no demand and replace them with courses with potential, such as in the area of Information Technology.

- Revamp and professionalize vocational courses by changing curricula to meet the needs of industry.

- Provide basic physical infrastructure, such as a proper building and laboratory for rural and backward area colleges.

- Provide opportunities to merited rural and economically deprived students to pursue research by providing fast-track promotions as well as monetary incentives.

\section{Conclusion:}

The education is only means of fulfill the objectives of social justice of our constitution. The negligence would be led to socio - economic and cultural inequalities and imbalance of the society and may also root cause for the rise of social evils, Naxalism, terrorism other illegal activities in the society.

\section{Reference:}

[1] Agarwal, P. (2006). Higher education in India: The need for change (Working paper \#180). Indian Council for Research on International Economic Relations. Retrieved April 22, 2007, from http://www.icrier.org/publication/working_papers_180.html

[2] Agarwal, P. (2007). Higher education in India: Growth, concerns and change agenda. Higher Education Quarterly, 61(2), 197-207.

[3] Aggarwal, J. C. (2004). Development of education system in India. Delhi, India: Shipra.

[4] Altbach, P. G,. Berdahl, R. O., \& Gumport, P. J. (Eds.). (2005). American higher education in the twenty-first century: Social, political, and economic challenges (2nd ed.). Baltimore: The Johns Hopkins University Press.

[5] Altbach, P. G. (1989). Twisted roots: The western impact on Asian higher education. Higher Education, 18(1), 9-29.

[6] Altbach, P. G. (2005a). Higher education in India. The Hindu. Retrieved May 24, 2007, from http://www.thehindu.com/2005/04/12/stories/2005041204141000.htm

[7] Altbach, P. G. (2005b). Academic corruption: The continuing challenge. International Higher Education, 38, 5-6. Retrieved September 25, 2007, from http://www.bc.edu/bc_org/avp/soe/cihe/newsletter/News38/text003.htm

[8] Altbach, P. G., \& Umakoshi, T. (Eds.). (2004). Asian universities: Historical perspectives and contemporary challenges. Baltimore: The Johns Hopkins University Press. 
[9] Altbach, P., (2003) American accreditation of foreign universities: colonialism in action, International Higher Education, 32, pp. 57 .

[10] Bagla, P. (2007). Beyond islands of excellence. Science, 317, 74-75.

[11] Bdrubd, M. and Nelson, C. (11995).' Introduction: A Report from the Front', in M. Berub6 and C. Nelson (eds.), Higher Education Under Fire. Politics, Economics, and the Crisis of the Humanities. New York: Routledge, pp. 1-32.

[12] Becker, H.S., Geer, B., Hughes, E.C. and Strauss, A.L. (1961). Boys in White: Student Culture in Medical School. Chicago: University of Chicago Press. Becker, H.S., Geer, B. and Hughes, E.C. (1968). Making the Grade: The Academic Side of College Life. New York: John Wiley.

[13] Beteille, A. (2007). Universities at the crossroads. Current Science, 92(4), 441-449.

[14] Birnbaum, R. (1983). Maintaining Diversity in Higher Education. Jossey-Bass Publishers, Washington.

[15] Bushnell, J. (1963). 'Student Culture at Vassar', in N. Sanford (ed.), The Anterican College. A Psychological and Social Interpretation of the Higher Learning. New York: John Wiley, pp.489-514.

[16] Clark, B. (1983). The Higher Education System: Academic organisation in cross-national perspective. University of California Press, Berkeley \& Los Angeles.

[17] Clark, B.R. (1963). 'Faculty Cultures', in T.F. Lunsford (ed.), The Study of Campus Cultures. Western Interstate Commission for Higher Education. Boulder, Colorado,p p. 39-54.

[18] Clark,B .R. (1970). The Distinctive College: Ree4 Antioch and Swarthmore. Chicago: Aldine.

[19] Clark,B .R. and Trow, M. (1966). 'The Organizational Context', in T.M. Newcomb and E.K. Wilson (eds.), College Peer Groups Chicago: Aldine, pp. 17-70.

[20] Currie, J. (2005) Globalization's impact on the professoriate in Anglo-American universities, in A. Welch (ed.) The Professoriate: Portrait of a profession., Springer, Dordrecht, pp. 21-34.

[21] Dressel, P.L. and Mayhew, L.B. (1974). Higher Education as a Field of Study. The Emergence of a Profession. San Francisco: Jossey-Bass.

[22] Enders, J. and de Weert, E. (2004a) Science, training and career: Changing modes of knowledge production and labour markets, Higher Education Policy, 17, pp. 135-152.

[23] EPW (Economic and Political Weekly). (2009, October 10). Editorial: Enabling the disabled, Economic and Political Weekly, XLIV(14), 7.

[24] Fulton, 0. (1992). 'Higher Education Studies', in B.R. Clark and G. Neave (eds.), The Ency-clopedia of Higher Education, Vol. 3. Oxford: Pergamon Press, pp. 1810-1821.

[25] Gabel, S.L. \& Chander, J.(2008). Inclusion in Indian education. New York : Peter Lang

[26] Giddens, A. (2001). The Great Globalization Debate. Zellerbach Distinguished Lecture. University of California, Berkeley. 25 October 2001

[27] Gu, M. (2001). Education in China and abroad: Perspectives from a lifetime in comparative education. Hong Kong: Comparative Education Research Center, University of Hong Kong.

[28] Hanh, P. N. (1998). The heart of the Buddha's teaching. New York: Broadway.

[29] Ho, I. (2001). Are Chinese teachers authoritarian? In D. A. Watkins, \& J. B. Biggs (Eds.), Teaching the Chinese learner: Psychological and pedagogical perspectives (pp. 99-114). Hong Kong: Comparative Education Research Centre, University of Hong Kong.

[30] India Year Book (2010), Government of India.

[31] Jarayam, N. (2004). Higher education in India: Massification and change. In P. G. Altbach, \& T. Umakoshi (Eds.), Asian universities: Historical perspectives and contemporary challenges (pp. 85-112). Baltimore: The Johns Hopkins University Press.

[32] Karnataka human development report 2000, Government of Karnataka.

[33] Karnataka human development report 2000, Government of Karnataka.

[34] Klasing, I. (2007), Disability and social exclusion in rural India, New Delhi, Rawat Publication.

[35] Lakhotia, S. C. (2005). India's ambitions to be a world leader in S\&T depend upon a drastic overhaul of the university system. Current Science, 88(11), 1731-1735.

[36] Mashelkar, R. A. (2005). India's R\&D: Reaching for the top. Science, 307, 1415-1417.

[37] Mehta, S., \& Whitebread, D. (2004). Philosophy for children and moral development in the Indian context. First Global Conference on Philosophy with Children. Retrieved September 8, 2007, http://www.cybercultures.net/ati/education/cp/cp1/mehta\%20paper.pdf

[38] Narayanan, R., \& Neethi, S. (2005). Creating human resources for information technology - A systemic study. NASSCOM IT workforce Development Group. Retrieved July 8, 2007, from http://www.nasscom.in/upload/52991/Dr_R_Narayanan.pdf

[39] Neave, G. (1996). 'Homogenization, Integration and Convergence: The Cheshire Cats of Higher Education Analysis', in L.V. Meek, L. Goedegebuure, 0. Kivinen and R. Rinne (eds.), The Mockers and Mocked: Comparative Perspectives on Differentiation, Convergence and Diversity in Higher Education. Guilford: Pergamon and IAU Press, pp. 26-41.

[40] Popli, S. (2005). Ensuring customer delight: A quality approach to excellence in management education. Quality in Higher Education, 11(1), 17-24.

[41] Radhakrishnan, S. (1990). Reader-An Anthology (p. 481). Bharatiya Vidya Bhavan Publication.

[42] Riesman, D. and Jencks, C. (1963). 'The Viability of the American College', in N. Sanford (ed.), The American College. A Psychological and Social Interpretatibn of the Higher Learning. New York: John Wiley, pp. 74-192.

[43] Rury, J. L. (2006). The curious status of the history of education. History of Education Quarterly, 46(4), 571-598.

[44] Russell, L. R. (2007). Innovation training in India: Cultural considerations and strategy implications. Performance Improvement Quarterly, submitted September 10, 2007. Retrieved September 27, 2007, from http://www.icainstitute.org/innovationindia_lr_russell.pdf.

[45] Stella, A. (2002). External quality assurance in Indian higher education: Case study of the National Assessment and Accreditation Council (NAAC). Paris: International Institute for Education Planning.

[46] Sweeting, A. (2005). The historical dimension: A contribution to conversation about theory and methodology in comparative education. Comparative Education, 41(1), 25-44.

[47] Sykes, M. (1987). The story of Nai Talim. Wardha: Nai Talim Samiti.

[48] Turner, Y. (2006). Chinese students in a UK business school: Hearing the student voice in reflective teaching and learning practice. Higher Education Quarterly, 60(1), 27-51.

[49] Tyler, R.W. (1963). 'The Study of Campus Cultures', in T.F. Lunsford (ed.), The Study of Campus Cultures. Western Interstate Commission for Higher Education. Boulder, Col-orado, pp. 1-10. 


\begin{tabular}{|c|c|c|c|c|c|}
\hline Economic class & $\begin{array}{l}\% \text { of the } \\
\text { population }\end{array}$ & $\begin{array}{l}\text { Social class/ } \\
\text { caste }\end{array}$ & $\begin{array}{l}\% \text { of the } \\
\text { population }\end{array}$ & Community & $\begin{array}{l}\% \text { of the } \\
\text { population }\end{array}$ \\
\hline Upper class & $30 \%$ & Upper caste & $7 \%$ & Urban community & $27 \%$ \\
\hline Middle elass & $40 \%$ & OBC & $57 \%$ & Rural eommunity & $63 \%$ \\
\hline Lower class & $30 \%$ & Lower/minorities & $36 \%$ & Tribal community & $10 \%$ \\
\hline Total & $100 \%$ & Total & $100 \%$ & Total & $100 \%$ \\
\hline
\end{tabular}

TABLE 02: UNIVERSITIES IN INDIA AS ON 2009-2010

\begin{tabular}{|l|l|}
\hline Universities & No of universities \\
\hline Central universities & 20 \\
\hline State universities & 215 \\
\hline Deemed universities & 100 \\
\hline Total colleges including women colleges in India. & 17000 \\
\hline
\end{tabular}

Source: India year book 2010.

TABLE 03: KARNATAKA EDUCATIONAL LITERACY PROFILE 1999-2000

\begin{tabular}{|l|c|}
\hline Level of education. & \% of the educational level. \\
\hline Higher education. & $12.14 \%$ \\
\hline Primary education. & $54.55 \%$ \\
\hline Secondary education. & $32.74 \%$ \\
\hline General education. & $0.02 \%$ \\
\hline Language education. & $0.53 \%$ \\
\hline Adult education. & $0.02 \%$ \\
\hline Total & $\mathbf{1 0 0 \%}$ \\
\hline
\end{tabular}

Source: Karnataka human development report 2000.

TABLE 04: KARNATAKA LITERACY PROFILE 1991-2001

\begin{tabular}{|l|l|l|}
\hline COMMUNITY & Literacy rate 1991 & Literacy rate 2001 \\
\hline Rural & 47.69 & 59.33 \\
\hline Urban & 74.02 & 80.58 \\
\hline Total literacy rate of Karnataka. & 56.04 & 66.64 \\
\hline
\end{tabular}

Source: Karnataka human development report 2005.

TABLE 05: ENROLMINT OF STUDENTS IN GENERAL DEGREE COLLEGES IN KARNATAKA

\begin{tabular}{|l|r|}
\hline General degree courses. & $\mathbf{2 0 0 3 - 2 0 0 4}$ \\
\hline Arts & 203898 \\
\hline Science & 82545 \\
\hline Commerce & 85770 \\
\hline Law & 22209 \\
\hline B.Ed. & 7126 \\
\hline Total & $\mathbf{4 0 1 5 4 8}$ \\
\hline
\end{tabular}

Source: Kamataka human development report 2005.

TABLE 06: ENTOLMINT OF STUDENTS IN PROFESSIONAL DEGREE COLLEGES IN KARNATAKA

\begin{tabular}{l|l|r|}
\hline Professional degree courses. & $\mathbf{2 0 0 3 - 2 0 0 4}$ \\
\hline Engineering & 84518 \\
\hline Medical & 2905 \\
\hline Dental & 2311 \\
\hline Pharmacy & 2349 \\
\hline Nursing & 5908 \\
\hline Ayurvedic & 2273 \\
\hline Homeopathy & 590 \\
\hline Whani & 126 \\
\hline Naturopathy & 69 \\
\hline Total & $\mathbf{1 0 1 0 4 9}$ \\
\hline
\end{tabular}

